\title{
Mutation of Three Cysteine Residues in Tomato yellow leaf curl virus-China C2 Protein Causes Dysfunction in Pathogenesis and Posttranscriptional Gene-Silencing Suppression
}

\author{
Rene van Wezel, ${ }^{1}$ Xiangli Dong, ${ }^{1}$ Huanting Liu, ${ }^{2}$ Po Tien, ${ }^{3}$ John Stanley, ${ }^{4}$ and Yiguo Hong ${ }^{1}$ \\ ${ }^{1}$ Department of Entomology and Plant Pathology, Horticulture Research International, East Malling, Kent ME19 6BJ, U.K.; \\ ${ }^{2}$ Department of Biology, University of St. Andrews, Fife KY16 9ST, U.K.; ${ }^{3}$ Department of Virology, Institute of Microbiology, \\ Beijing 100080, China; and ${ }^{4}$ Department of Disease and Stress Biology, John Innes Centre, Colney, Norwich NR4 7UH, \\ U.K.
}

Submitted 4 September 2001. Accepted 10 November 2001.

The nuclear localized $\mathrm{C} 2$ protein of the monopartite begomovirus Tomato yellow leaf curl virus-China (TYLCV-C) contributes to viral pathogenicity. Here, we have investigated TYLCV-C C2 protein domains that play a role in the phenotype. Alignment of the $\mathrm{C} 2$ protein with 67 homologues from monopartite and bipartite begomoviruses revealed that a putative zinc-finger motif $\mathrm{C}_{36^{-}} \mathrm{X} 1-\mathrm{C}_{38^{-}}-\mathrm{X7}-\mathrm{C}_{46^{-}}$ $\mathrm{X6}-\mathrm{H}_{53}-\mathrm{X} 4-\mathrm{H}_{58} \mathrm{C}_{59}$ and four potential phosphorylation sites $\left(T_{52}, S_{61}, Y_{68}\right.$, and $\left.S_{74}\right)$ are highly conserved. When expressed from a Potato virus $X(\mathrm{PVX})$ vector, TYLCV-C C2 protein mutants C2-T52M, C2-H58S, C2-C59S, C2-S61R, and $\mathrm{C2}-\mathrm{S} 74 \mathrm{D}$, like the wild-type $\mathrm{C} 2$ protein, induced local necrotic ringspots and systemic necrosis in Nicotiana benthamiana plants. Mutants C2-H53P and C2-Y68D produced irregular necrotic lesions on inoculated leaves that were distinct from the wild-type phenotype. In contrast, mutants C2-C36R, C2-C38N, and C2-C46I induced chlorosis and mosaic symptoms rather than necrosis. We demonstrate that TYLCV-C C2, like its counterpart in the bipartite begomovirus African cassava mosaic virus, mediates suppression of posttranscriptional gene silencing (PTGS). Moreover, the individual mutations C36R, C38N, and C46I abolished the ability of $\mathrm{C} 2$ protein to suppress PTGS. These results suggest that the three cysteine residues within the putative zinc-finger motif are essential for $\mathrm{C2}$ protein to induce necrosis and to act as a suppressor of PTGS.

Additional keywords: counter-defense, Geminiviridae.

Members of the family Geminiviridae are unique small circular single-stranded (ss) plant DNA viruses that replicate in the nucleus via double-stranded (ds) DNA intermediates by a rolling circle mechanism (Hanley-Bowdoin et al. 1999). The monopartite geminivirus Tomato yellow leaf curl virus-China (TYLCV-C) belongs to the genus Begomovirus (Yin et al. 2001). Similar to Tomato yellow leaf curl virus-Israel (TYLCV-Is), Tomato yellow leaf curl virus-Sardinia (TYLCVS), Tomato leaf curl virus-Australia (ToLCV-Au), and Ageratum yellow vein virus, TYLCV-C has a monopartite genome resembling the bipartite begomovirus DNA A component,

Corresponding author: Yiguo Hong; E-mail: yiguo.hong@hri.ac.uk typified by African cassava mosaic virus (ACMV) and Tomato golden mosaic virus (TGMV) (Dry et al. 1993; Hamilton et al. 1984; Kheyr-Pour et al. 1991; Navot et al. 1991; Stanley and Gay 1983; Tan et al. 1995). Geminiviruses encode several proteins required for viral DNA replication, regulation of gene expression, and virus movement in plants. One of the viral proteins is the transcriptional activator protein (TrAP, also known as AL2 or AC2). TrAP of TGMV and ACMV is involved in the regulation of viral coat protein $(\mathrm{CP})$ and nuclear shuttle protein expression (Brough et al. 1992; Groning et al. 1994; Haley et al. 1992; Hartitz et al. 1997; Hong et al. 1996; Sunter and Bisaro 1991, 1992, 1997). TGMV TrAP is a phosphoprotein and binds zinc to facilitate optimal TrAP-ssDNA interaction. Its C-terminal acidic domain has been implicated in transcriptional activation (Hartitz et al. 1997). ACMV TrAP contributes to viral pathogenicity and acts as an efficient suppressor of posttranscriptional gene silencing (PTGS), a plant defense system against virus attack (Voinnet et al. 1999).

The monopartite begomovirus $\mathrm{C} 2$ protein, similar to its homologue TrAP, possesses an N-terminal basic domain, a Cterminal acidic domain, and an intervening core region containing a zinc-finger motif. An in vitro DNA binding assay indicated that TYLCV-S C2 protein, like TrAP, exhibited sequence-nonspecific ssDNA and dsDNA binding activity (Hartitz et al. 1997; Noris et al. 1996; Sung and Coutts 1996). On the other hand, genetic analysis suggested that TYLCV-S $\mathrm{C} 2$ protein plays a role in virus systemic spread and ToLCV$\mathrm{Au} \mathrm{C} 2$ protein regulates $\mathrm{CP}$ expression in planta, although the mechanisms remain to be established (Dry et al. 2000; Wartig et al. 1997). Recently, we showed that TYLCV-C C2 protein is localized in nuclei and is a pathogenicity determinant. Expression of TYLCV-C C2 protein in Nicotiana benthamiana plants from a Potato virus $X$ (PVX) vector induced necrotic ringspots on inoculated leaves (van Wezel et al. 2001). Here, using PVX-mediated expression of TYLCV-C C2 protein mutants, we have identified amino acid residues that are required for viral pathogenesis and suppression of PTGS.

\section{RESULTS}

PVX-based constructs for expression of $\mathrm{C} 2$ protein and its mutant derivatives in plants.

TYLCV-C gene $C 2$ encodes a small protein consisting of 134 amino acids. When compared to the TrAP homologues of 
TGMV and TYLCV-S (Hartitz et al. 1997; Noris et al. 1996), three putative functional domains were assigned to the amino acid sequence of the TYLCV-C C2 protein (Fig. 1). Amino acids 1 to 31 represent the $\mathrm{N}$-terminal basic domain with a putative nuclear localization signal, amino acids 32 to 104 are the central core which may have DNA binding activity, and amino acids 105 to 134 may represent the $\mathrm{C}$-terminal acidic domain responsible for transcriptional activation of gene expression. Alignment of the amino acid sequences of the TYLCV-C C2 protein and 67 homologues from monopartite and bipartite begomoviruses revealed that $\mathrm{C} 2$ protein has a highly conserved putative zinc-finger motif $\mathrm{C}_{36}-\mathrm{X} 1-\mathrm{C}_{38}-\mathrm{X} 7-\mathrm{C}_{46}-\mathrm{X} 6-\mathrm{H}_{53}-\mathrm{X} 4-$ $\mathrm{H}_{58} \mathrm{C}_{59}$ and four highly conserved potential phosphorylation sites $\left(T_{52}, S_{61}, Y_{68}\right.$, and $\left.S_{74}\right)$ (Fig. 1). These amino acid residues were targeted for mutagenesis analysis to test whether or not

Table 1. Primers used for mutagenesis

\begin{tabular}{|c|c|c|}
\hline Primer & Sequence $\left(5^{\prime}-3^{\prime}\right)^{a}$ & $\begin{array}{l}\text { Modification } \\
\text { introduced }\end{array}$ \\
\hline PP47 & GGCTGTAatcgATGCGATCTTCG $^{\mathrm{b}}$ & $\mathrm{ClaI}^{\mathrm{c}}$ \\
\hline PP48 & GGCTGTAatcgATGtGATCTTCG ${ }^{b}$ & $C l a I^{\mathrm{d}}$ \\
\hline PP49 & ATTGGcggccgAATACTCTTAAGAAATG & EagI \\
\hline PP54 & GCTGCAGgacGTcGTTCCCCTGTG & Aat II \\
\hline PP55 & GGAACgACgtcCTGCAGCTCAA ${ }^{\mathrm{b}}$ & Aat II \\
\hline PP57 & GTTCCССТаTGCaTGAATCCATGATTG & NsiI \\
\hline PP58 & GATTCAtGCAtAGGGGAACTACTCA ${ }^{\mathrm{b}}$ & NsiI \\
\hline PP59 & ATTCTCTGATTctagaGCAGTGAGTAG & $X b a \mathrm{I}$ \\
\hline PP60 & CACTGCtctagAATCAGAGAATGGC ${ }^{\mathrm{b}}$ & $X b a \mathrm{I}$ \\
\hline PP61 & GTCCAGATcTACACGCCATTCTCTG & $B g l I I$ \\
\hline PP62 & TGGCGTGTAgATCTGGACGGTC $^{\mathrm{b}}$ & BglII \\
\hline PP63 & ATACAGGatccTTTTGACCGTCCAG & BamHI \\
\hline PP64 & GGTCAAAAggatCCTGTATTTCAAG ${ }^{\mathrm{b}}$ & BamHI \\
\hline PP65 & CAACCcCtAGGTAGATCAACCCG & AvrII \\
\hline PP66 & TGATCTACCTaGgGGTTGTTCTTAC ${ }^{b}$ & AvrII \\
\hline PP67 & GTAAGAAttcCCACAAGGTAG & EcoRI \\
\hline PP68 & GTGGgaaTTCTTACTTCGTTG ${ }^{\mathrm{b}}$ & EcoRI \\
\hline PP69 & ATTGTGAattCCTAAAGCAACGAAG & EcoRI \\
\hline PP70 & GCTTTAGGaatTCACAATCATGG & EcoRI \\
\hline PP71 & TAGTTCC高TagGCGTGAATCC & AvrII \\
\hline PP72 & TCACGCetAGGGGAACTACTC ${ }^{\mathrm{b}}$ & AvrII \\
\hline PP73 & CTGATTGAGCTcgAGTGAGTAGTTC & XhoI \\
\hline PP74 & CTACTCACTcgAGCTCAATCAGAGAAT & XhoI \\
\hline \multicolumn{3}{|c|}{$\begin{array}{l}\text { a Introduced restriction endonuclease sites are underlined, modified nu- } \\
\text { cleotides are in lower case and mutated codons are in bold font. } \\
\text { b Coding strand primers; others are complementary to the coding strand. } \\
{ }^{c} \text { C2 start codon ATG italicised. }\end{array}$} \\
\hline
\end{tabular}

they are involved in TYLCV-C C2 protein-mediated pathogenesis in plants. To achieve this, $10 \mathrm{C} 2$ protein mutants, each having a single mutated amino acid, were produced (Tables 1 and 2).

\section{Effects of individual amino acid replacement on $\mathrm{C2}$ protein-mediated induction of necrosis in $N$. benthamiana.}

RNA transcripts produced by in vitro transcription from each of the PVX constructs were infectious in N. benthamiana. The accumulation of viral RNAs reached a similar level in infected plants as shown by northern blot analysis (Fig. 2). Viral genomic $(6.9 \mathrm{~kb})$ and subgenomic RNAs $(2.6$ and $1.4 \mathrm{~kb})$ containing either wild-type or mutant gene $C 2$ were detected in systemically infected tissues using either PVX- or $C 2$ genespecific probes (Fig. 2A and B). As expected, the PVX CP subgenomic RNA (0.9 kb) was only detectable using a PVXspecific probe (Fig. 2B). These results suggested that the $C 2$ gene and its mutant derivatives were maintained during PVX infection, and that wild-type and mutant $\mathrm{C} 2$ proteins should be expressed to comparable levels from the 1.4-kb subgenomic RNA under the control of the duplicated PVX CP promoter.

The biological effect of expression of wild-type and mutant C2 proteins was assessed by symptom development in plants infected with the PVX recombinants. Local lesions developed 3 to 5 days postinoculation (dpi) and systemic symptoms 6 to 7 dpi. Typical local symptoms on leaves inoculated with either $\mathrm{PVX} / \mathrm{C} 2$, $\mathrm{PVX} / \mathrm{mC} 2$, or PVX expressing C2 proteins containing single amino acid substitutions are shown in Figure 3. As reported previously, the wild-type $\mathrm{C} 2$ protein expressed from $\mathrm{PVX} / \mathrm{C} 2$ induced unusual necrotic ringspots on inoculated leaves and necrotic vein banding on systemically infected leaves, whereas the nonsense mutant expressed from $\mathrm{PVX} / \mathrm{mC} 2$ produced typical PVX local chlorotic lesions and systemic chlorosis and mosaic symptoms (van Wezel et al. 2001). The point mutations T52M, H58S, C59S, S61R, and S74D had little effect on C2 protein-mediated necrosis. Although expression of missense mutants $\mathrm{C} 2-\mathrm{H} 53 \mathrm{P}$ and $\mathrm{C} 2-$ Y68D induced necrosis, these two mutants produced irregular local necrotic lesions rather than the typical necrotic ringspots. Infection of plants by PVX/C2-C36R, PVX/C2-C38N, or $\mathrm{PVX} / \mathrm{C} 2-\mathrm{C} 46 \mathrm{I}$ did not produce a necrotic phenotype but induced chlorotic lesions on the inoculated leaves and systemic chlorosis and mosaic symptoms.

Consistent with northern blot analysis, gene $C 2$ RNAs were detectable in infected plants by reverse transcriptase-poly-

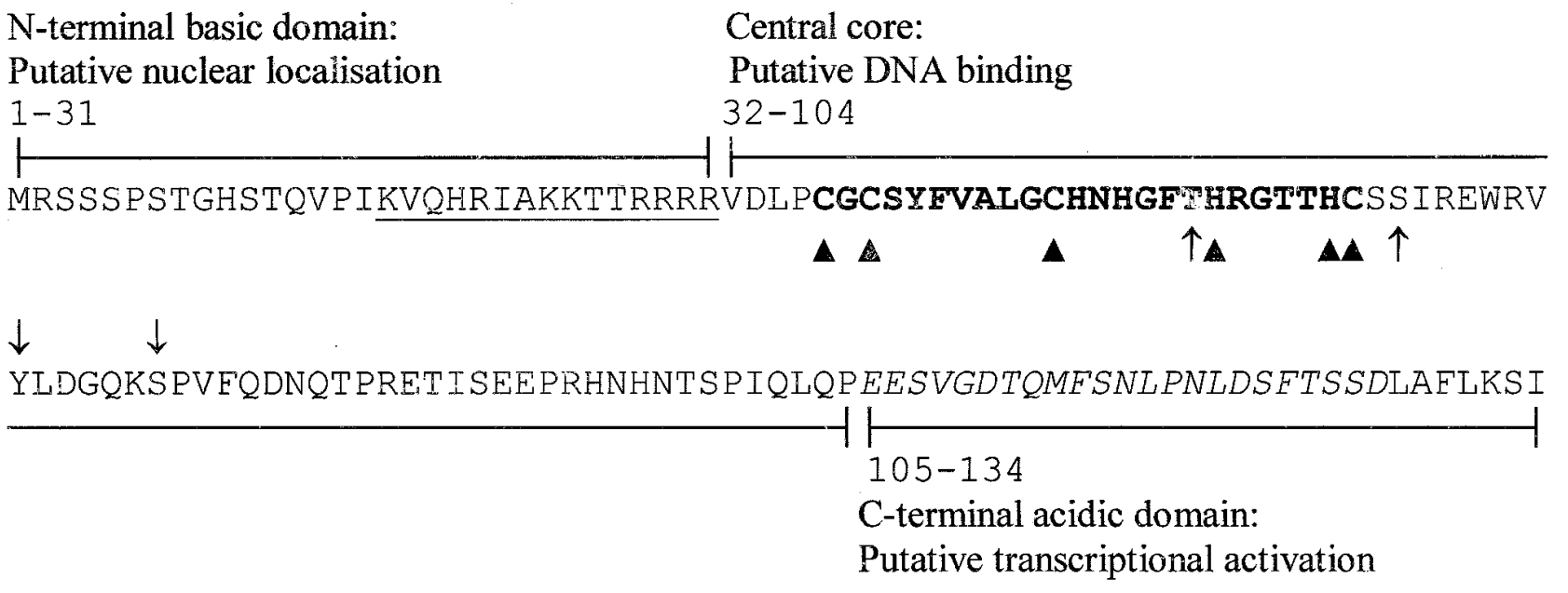

Fig. 1. Amino acid sequence and potential functional domains of Tomato yellow leaf curl virus-China $\mathrm{C} 2$ protein. The putative nuclear localization signal is underlined. The putative zinc-finger motif is in bold. The aspartic acid and glutamic acid rich region is italicized. Conserved cysteine and histidine residues are indicated by $\boldsymbol{\Delta}$. Potential phosphorylation sites are indicated by arrows. 
merase chain reaction (RT-PCR). Primers PP47 and PP49 allowed the amplification of a 424-bp fragment specific to gene $C 2$ using RNA extracts from plants infected with $\mathrm{PVX} / \mathrm{C} 2$, $\mathrm{PVX} / \mathrm{mC} 2$, or PVX expressing C2 missense mutants (Fig. 4A). Specific restriction endonuclease digestion of each RT-PCR product yielded DNA fragments with the predicted sizes (Fig. $4 \mathrm{~B}$ and C). Sequence analysis of RT-PCR products confirmed that neither reversion nor random spontaneous mutations had occurred in gene $C 2$ during infection. These analyses showed that wild-type and mutant $\mathrm{C} 2$ proteins expressed in plants from PVX-based vectors had maintained their integrity. Our results demonstrate that the three cysteine residues, $\mathrm{C}_{36}, \mathrm{C}_{38}$, and $\mathrm{C}_{46}$, impose a significant influence on $\mathrm{C} 2$ protein-mediated pathogenesis and amino acids $\mathrm{H}_{53}$ and $\mathrm{Y}_{68}$ may also contribute to this process.

\section{C2 protein is a suppressor of PTGS.}

To test whether it acts as a suppressor of PTGS, the TYLCV-C C2 protein was expressed as a green fluorescent protein (GFP) fusion protein from the PVX-based vector in transgenic $N$. benthamiana line $16 \mathrm{c}$. $N$. benthamiana line $16 \mathrm{c}$ carries a single copy of the GFP gene under the control of the $35 \mathrm{~S}$ promoter. Plants challenged with PVX developed typical local chlorotic lesions, and mosaic and chlorotic symptoms on systemically infected leaves. PVX infection had no effect on GFP expression in these plants (Fig. 5) which, like mock-inoculated plants, showed green fluorescence under long-wavelength UV light. However, plants inoculated with either PVX/GFP or PVX/mC2-GFP developed systemic symptoms by $7 \mathrm{dpi}$, but later recovered and showed only a very mild mosaic phenotype on young leaves. Silencing of GFP expression in these plants was first apparent approximately 7 dpi and was almost complete by 15 dpi. Under the same experimental conditions, plants infected with PVX/C2-GFP developed necrotic ringspots on the inoculated leaves and systemic necrosis. No recovery of infection was observed in these plants, and silencing did not occur (Fig. 5). In view of the dramatic effect of the three cysteine mutations on $\mathrm{C} 2$ protein-mediated pathogenesis, we also investigated whether these missense mutant proteins had altered silencing properties. Plants inoculated with PVX/C2-C36R-GFP, PVX/C2-C38N-GFP, and PVX/C2-C46IGFP, like those infected with PVX/GFP and PVX/mC2-GFP, showed significant recovery from infection, and suppression of $g f p$ gene silencing did not occur (Fig. 5).

The level of viral RNAs and $g f p$ transgene mRNA in infected plants was investigated by northern blot analysis using C2-, PVX- and gfp-specific probes (Fig. 6). Consistent with the recovery phenotype, recombinant PVX RNAs were almost undetectable in plants challenged with PVX/mC2-GFP,
PVX/C2-C36R-GFP, PVX/C2-C38N-GFP, and PVX/C2-C46IGFP. However, considerable amounts of PVX genomic and subgenomic RNAs were detected in plants infected with PVX/C2-GFP (Fig. 6). Indeed, a similar amount of viral RNAs was detected in plants showing no silencing and silencing suppression, associated with PVX and PVX/C2-GFP infection, respectively. Moreover, transgene $g f p$ mRNA was only detected in mock-inoculated plants and in plants infected with either PVX or PVX/C2-GFP (Fig. 6C). Taken together, our data demonstrate that TYLCV-C C2 protein can suppress PTGS of both the $g f p$ transgene and the $g f p$ gene inserted into the PVX genome. The three cysteine missense mutations in the putative zinc-binding motif, described above, abolished the ability of C2 protein to suppress PTGS.

\section{DISCUSSION}

TrAP encoded by bipartite begomoviruses activates virionsense gene expression at the level of transcription, contributes to viral pathogenicity and suppresses PTGS (Hanley-Bowdoin et al. 1999; Hong et al. 1997; van Wezel et al. 2001; Voinnet et al. 1999). TrAP, a zinc-binding phosphoprotein, interacts with ssDNA in preference to dsDNA in a sequence-nonspecific manner (Hartitz et al. 1997; Noris et al. 1996; Sung and Coutts 1996). However, lack of correlation between TrAP biochemical and biological properties confounds our understanding of the mechanisms by which it carries out these apparently distinct functions. We have initiated the functional analysis of gene $C 2$ of the monopartite begomovirus TYLCV-C that expresses a protein homologue of bipartite begomovirus TrAP. We have demonstrated that none of the four highly conserved potential phosphorylation sites $\left(\mathrm{T}_{52}, \mathrm{~S}_{61}, \mathrm{Y}_{68}\right.$, and $\left.\mathrm{S}_{74}\right)$ is essential for $\mathrm{C} 2$ protein-mediated necrosis, although mutation of $\mathrm{Y}_{68}$ produced a different necrotic phenotype, which may imply that phosphorylation at this position occurs in plants. Although TGMV TrAP is known to be a phosphoprotein (Hartitz et al. 1997), it may be that phosphorylation is not a prerequisite for TrAP-mediated pathogenesis but is required for other functions involving the control of viral or possibly host gene expression. Additionally, TrAP may be phosphorylated at less conserved amino acids rather than those mutated here. Indeed, amino acid sequence comparisons have shown that there were several potential phosphorylation sites present in New World begomovirus TrAPs that are absent in their Old World begomovirus counterparts, and vice versa (unpublished data).

Our results demonstrate that the motif $\mathrm{C}_{36}-\mathrm{X} 1-\mathrm{C}_{38^{-}} \mathrm{X} 7-\mathrm{C}_{46^{-}}$ $\mathrm{X} 6-\mathrm{H}_{53}$, which is conserved in TrAP homologues of all begomoviruses sequenced so far, may be biologically functional in $\mathrm{C} 2$ protein-mediated pathogenesis. The three cysteine residues

Table 2. Construction of $\mathrm{C} 2$ protein mutants

\begin{tabular}{|c|c|c|c|}
\hline Construct & Primer pair $^{\mathrm{a}}$ & Cloning sites $^{\mathbf{b}}$ & Amino acid mutated \\
\hline $\mathrm{PVX} / \mathrm{C} 2$ & PP47/PP49 & ClaI/EagI & wild type \\
\hline $\mathrm{PVX} / \mathrm{mC} 2$ & PP48/PP49 & ClaI/EagI & nonsense mutant \\
\hline $\mathrm{PVX} / \mathrm{C} 2-\mathrm{C} 36 \mathrm{R}$ & PP47/PP65 + PP66/PP49 & ClaI/AvrII + AvrII/EagI & Cys $\rightarrow$ Arg \\
\hline $\mathrm{PVX} / \mathrm{C} 2-\mathrm{C} 38 \mathrm{~N}$ & PP47/PP67 + PP68/PP49 & ClaI/EcoRI + EcoRI/EagI & Cys $\rightarrow$ Asn \\
\hline PVX/C2-C46I & PP47/PP69 + PP70/PP49 & ClaI/EcoRI + EcoRI/EagI & Cys $\rightarrow$ Ile \\
\hline $\mathrm{PVX} / \mathrm{C} 2-\mathrm{T} 52 \mathrm{M}$ & PP47/PP57 + PP58/PP49 & ClaI/NsiI + NsiI/EagI & Thr $\rightarrow$ Met \\
\hline $\mathrm{PVX} / \mathrm{C} 2-\mathrm{H} 53 \mathrm{P}$ & $\mathrm{PP} 47 / \mathrm{PP} 71+\mathrm{PP} 72 / \mathrm{PP} 49$ & ClaI/AvrII + AvrII/EagI & His $\rightarrow$ Pro \\
\hline $\mathrm{PVX} / \mathrm{C} 2-\mathrm{H} 58 \mathrm{~S}$ & PP47/PP54 + PP55/PP49 & ClaI/Aat II + AatII/EagI & His $\rightarrow$ Ser \\
\hline $\mathrm{PVX} / \mathrm{C} 2-\mathrm{C} 59 \mathrm{~S}$ & PP47/PP73 + PP74/PP49 & ClaI/XhoI + XhoI/EagI & Cys $\rightarrow$ Ser \\
\hline PVX/C2-S61R & PP47/PP59 + PP60/PP49 & $C l a \mathrm{I} / X b a \mathrm{I}+X b a \mathrm{I} / E a g \mathrm{I}$ & Ser $\rightarrow$ Arg \\
\hline $\mathrm{PVX} / \mathrm{C} 2-\mathrm{Y} 68 \mathrm{D}$ & PP47/PP61 + PP62/PP49 & ClaI/BglII + BglII/EagI & Tyr $\rightarrow$ Asp \\
\hline $\mathrm{PVX} / \mathrm{C} 2-\mathrm{S} 74 \mathrm{D}$ & PP47/PP63 + PP64/PP49 & ClaI/BamHI + BamHI/EagI & Ser $\rightarrow$ Asp \\
\hline
\end{tabular}

${ }^{a}$ Either PP47 with the indicated noncoding strand primer or PP49 with the indicated coding strand primer were used for PCR amplification of the 5' and $3^{\prime}$ regions of TYLCV-C gene $C 2$.

${ }^{\mathrm{b}}$ The PCR products of the $5^{\prime}$ and $3^{\prime}$ region of gene $C 2$ were digested with either $C l a \mathrm{I}$ or EagI and the indicated restriction endonuclease, and cloned into the ClaI/EagI sites of p45P46. 
$\mathrm{C}_{36}, \mathrm{C}_{38}$, and $\mathrm{C}_{46}$ are essential for this function whereas mutation of $\mathrm{H}_{53}$ has a slight effect on the necrotic phenotype. Although extremely conserved, amino acids $\mathrm{H}_{58}$ and $\mathrm{C}_{59}$ exerted no obvious effect on the phenotype. Furthermore, we have provided experimental evidence that the $\mathrm{C} 2$ protein, like ACMV TrAP, is a suppressor of PTGS. Moreover, cysteine residues $\mathrm{C}_{36}, \mathrm{C}_{38}$, and $\mathrm{C}_{46}$ in the putative zinc-finger motif are essential for $\mathrm{C} 2$ protein to suppress PTGS. Investigation of the contribution of the $\mathrm{C}_{36}-\mathrm{X} 1-\mathrm{C}_{38}-\mathrm{X} 7-\mathrm{C}_{46}-\mathrm{X} 6-\mathrm{H}_{53}$ motif to zinc binding and whether the three cysteine mutations affect zinc-

$$
\begin{array}{llllllllllllll}
1 & 2 & 3 & 4 & 5 & 6 & 7 & 8 & 9 & 10 & 11 & 12 & 13 & 14
\end{array}
$$

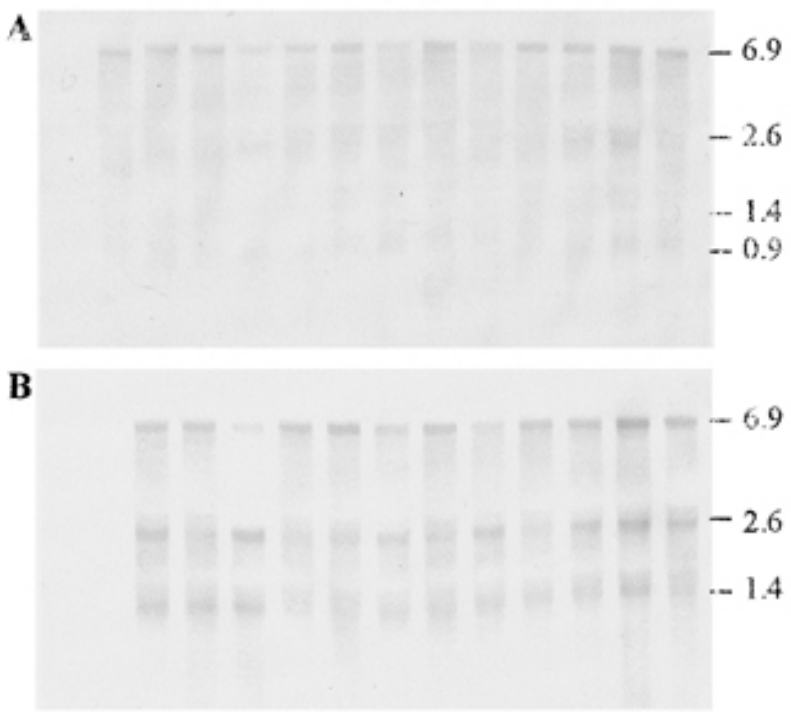

Fig. 2. Northern blot analysis of RNAs extracted 7 days postinoculation from mock-inoculated (lane 1) and virus-infected (lanes 2-14) plants. Lane 2, Potato virus X (PVX); lane 3, PVX/C2; lane 4, PVX/mC2; lane 5, PVX/C2-C36R; lane 6, PVX/C2-C38N; lane 7, PVX/C2-C46I; lane 8, PVX/C2-T52M; lane 9, PVX/C2-H53P; lane 10, PVX/C2-H58S; lane 11, PVX/C2-C59S; lane 12, PVX/C2-S61R; lane 13, PVX/C2-Y68D; lane 14, PVX/C2-S74D. Blots were hybridized with digoxigenin-labeled probes specific to $\mathbf{A}, \mathrm{PVX}$ or $\mathbf{B}$, gene $C 2$ sequences. The positions and sizes $(\mathrm{kb})$ of the genomic and subgenomic RNAs are indicated at the right.

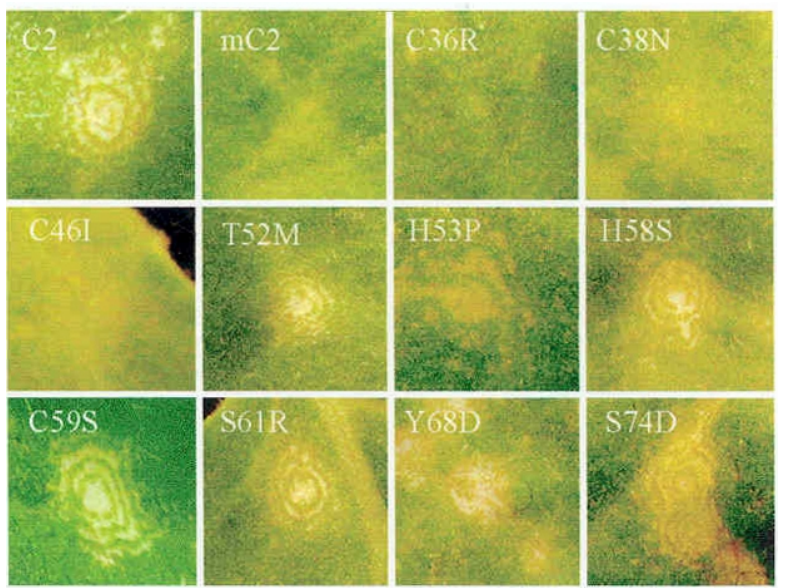

Fig. 3. Phenotypes on inoculated Nicotiana benthamiana leaves. The panels show necrotic ringspots on leaves inoculated with Potato virus $X$ (PVX)/C2 (C2), PVX/C2-T52M (T52M), PVX/C2-H58S (H58S), PVX/C2-C59S (C59S), PVX/C2-S61R (S61R), and PVX/C2-S74D (S74D); irregular necrotic lesions on leaves inoculated with PVX/C2$\mathrm{H} 53 \mathrm{P}$ (H53P) and PVX/C2-Y68D (Y68D); and chlorotic lesions on leaves inoculated with $\mathrm{PVX} / \mathrm{mC} 2(\mathrm{mC} 2), \mathrm{PVX} / \mathrm{C} 2-\mathrm{C} 36 \mathrm{R}$ (C36R), PVX/C2C38N (C38N), and PVX/C2-C46I (C46I). Leaves were photographed 7 days postinoculation. binding activity and the optimal interaction of the $\mathrm{C} 2$ protein with dsDNA and ssDNA is currently ongoing. It also will be interesting to examine whether this motif plays a direct role in the regulation of virion-sense gene expression.

PTGS occurs through homology-dependent degradation of RNA and is regarded as a fundamental process related to a wide range of epigenetic phenomena. In plants, PTGS represents an effective defense system against virus infection. On the other hand, plant RNA and DNA viruses have evolved a counter-defense mechanism by encoding suppressors of PTGS, which often contribute to viral pathogenicity. PTGS suppressors characterized so far include $2 \mathrm{~b}$, HC-Pro, P1, and P19 proteins from cucumoviruses, potyviruses, sobemoviruses, tombusviruses, PVX p25 movement protein, ACMV AC2 (TrAP) (Carrington et al. 2001; Voinnet 2001), and TYLCV-C C2 protein described here. There is much variation in the extent of suppression of PTGS by different viruses (Voinnet et al. 1999). Indeed, such proteins mediate suppression by targeting different steps in the PGTS pathway (Anandalakshmi et al. 2000; Voinnet et al. 2000). Considering the biochemical properties, nuclear localization, and biological functions involved in specific modulation of gene expression, the mechanism of suppressing PTGS triggered by TYLCV-C $\mathrm{C} 2$ protein and its ACMV homologue may be distinct and remains to be elucidated.

\section{MATERIALS AND METHODS}

\section{Plasmid constructs.}

Ten individual C2 protein mutants, each of which had a single amino acid replaced with another of unrelated physicochemical properties, were constructed. The primers shown in

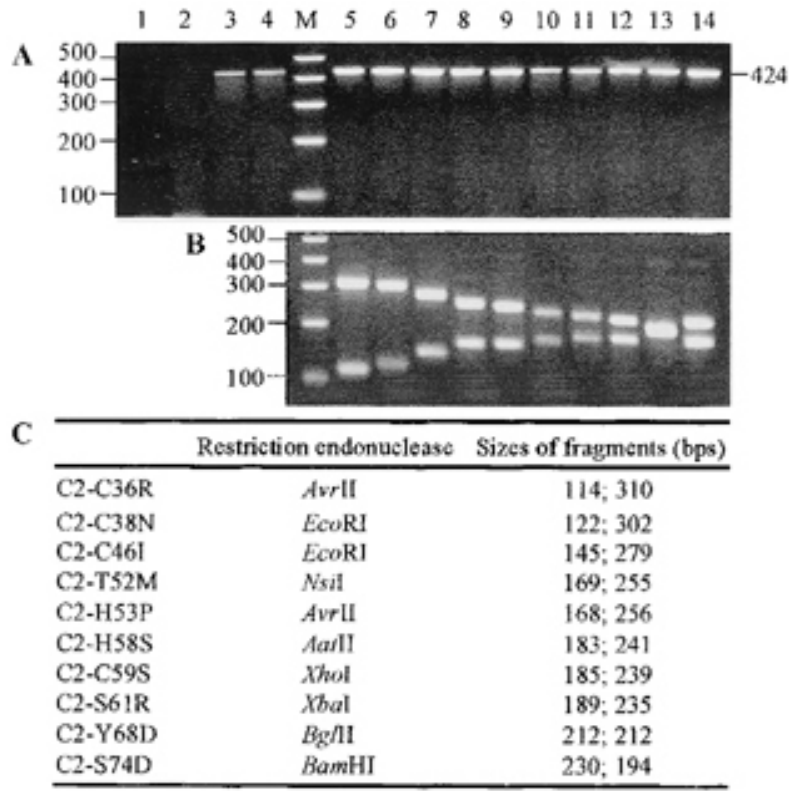

Fig. 4. Detection of $\mathrm{C} 2$ protein mutations by reverse transcriptasepolymerase chain reaction (RT-PCR) analysis. RNA was extracted 7 days postinoculation from mock-inoculated (lane 1, negative control) and virus-infected (lanes 2-14) plants. Lane 2, Potato virus X (PVX); lane 3, $\mathrm{PVX} / \mathrm{C} 2$; lane 4, PVX/mC2; lane 5, PVX/C2-C36R; lane 6, PVX/C2C38N; lane 7, PVX/C2-C46I; lane 8, PVX/C2-T52M; lane 9, PVX/C2H53P; lane 10, PVX/C2-H58S; lane 11, PVX/C2-C59S; lane 12, PVX/C2-S61R; lane 13, PVX/C2-Y68D; lane 14, PVX/C2-S74D; Lane M, 1-kb DNA ladder (Invitrogen, Groningen, The Netherlands). A, 1.4\% agarose gel electrophoresis of $C 2$ gene specific RT-PCR products. The size (bp) of RT-PCR products is indicated. B and $\mathbf{C}$, Restriction endonuclease analysis of RT-PCR products. The positions and sizes of DNA markers (bp) are indicated to the left of each gel. 
Table 1 were designed to introduce specific restriction endonuclease sites in the $\mathrm{C} 2$ protein coding sequence in order to modify selected amino acids. Sequences corresponding to $5^{\prime}$ and $3^{\prime}$ regions of the $C 2$ gene were amplified by PCR using either PP47 and the appropriate noncoding strand primer or PP49 and the appropriate coding strand primer. PCR products corresponding to the two halves of the gene were digested with either ClaI or EagI, together with the restriction endonuclease appropriate to the introduced site, and were cloned into ClaI/EagI-digested PVX-based vector p45P46 (van Wezel et al. 2001) to produce the mutants described in Table 2. Each of the mutations was confirmed by restriction endonuclease analysis and nucleotide sequencing. The wild-type $\mathrm{C} 2$ protein coding sequence and a nonsense mutant derivative were PCR-amplified using primer pairs PP47/PP49 and PP48/PP49, respectively, and were cloned as ClaI/EagI fragments into p45P46 as previously described to produce $\mathrm{PVX} / \mathrm{C} 2$ and $\mathrm{PVX} / \mathrm{mC} 2$ (van Wezel et al. 2001).

\section{Virus infection and plant maintenance.}

RNA transcripts were produced by in vitro transcription from each of the PVX constructs after linearization with SpeI, and mechanically inoculated to $N$. benthamiana plants as described (Chapman et al. 1992). Plants were maintained in an

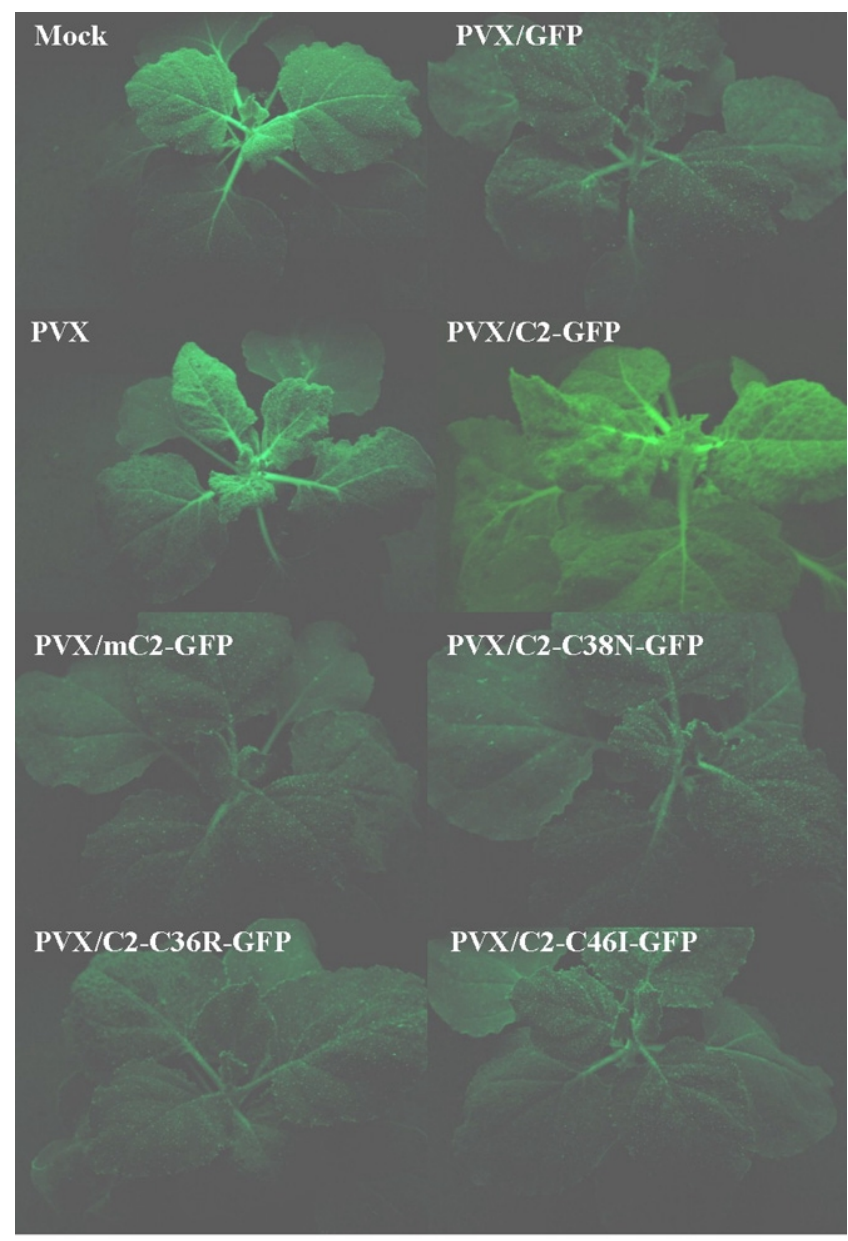

Fig. 5. Suppression of posttranscriptional gene silencing in green fluorescent protein (GFP) transgenic Nicotiana benthamiana plants by Tomato yellow leaf curl virus-China $\mathrm{C} 2$ protein. Plants were observed under longwavelength UV illumination through a Wratten 58 (green) filter at 15 days postinoculation. Green fluorescence occurs in mock inoculated and Potato virus $X(\mathrm{PVX})$ - and PVX/C2-GFP-infected transgenic plants. Silencing of gfp expression occurs in transgenic plants infected with PVX/GFP, PVX/mC2-GFP, PVX/C2-C36R-GFP, PVX/C2-C38N-GFP, and PVX/C2C46I-GFP. insect-free growth room at $25^{\circ} \mathrm{C}$ with continuous lighting to give a 12-h photoperiod. Local and systemic symptom development in inoculated plants was assessed on a daily basis and photographically recorded using a Nikon Digital Camera Coolpix990.

\section{RNA extraction and northern blot analysis.}

Total RNAs were extracted from leaf tissues using an RNeasy plant mini kit (Qiagen, Hilden, Germany). RNA aliquots $(2.5 \mu \mathrm{g})$ were fractionated on a $1 \%$ formaldehyde agarose gel, transferred to nylon membrane, hybridized with digoxigenin (DIG)-labeled probes specific to either PVX, $C 2$, or gfp gene sequences, and immunodetected using a DIG DNA labeling and detection kit (Roche Diagnostics, Mannheim, Germany).

\section{PTGS suppression assay.}

The GFP coding sequence was isolated from TXS.GFP-CP (Santa Cruz et al. 1996) as an EagI/BspEI fragment and fused in-frame to the coding sequences of $\mathrm{C} 2-\mathrm{C} 36 \mathrm{R}, \mathrm{C} 2-\mathrm{C} 38 \mathrm{~N}$, and C2-C46I in PVX/C2-C36R, PVX/C2-C38N, and PVX/C2C46I, to produce PVX/C2-C36R-GFP, PVX/C2-C38N-GFP, and PVX/C2-C46I-GFP, respectively. PVX/GFP, PVX/C2GFP, and PVX/mC2-GFP were constructed as described previously (van Wezel et al. 2001). Seedlings of transgenic N. benthamiana line 16c carrying the gfp gene (Brigneti et al. 1998) were mechanically inoculated with RNA transcripts produced
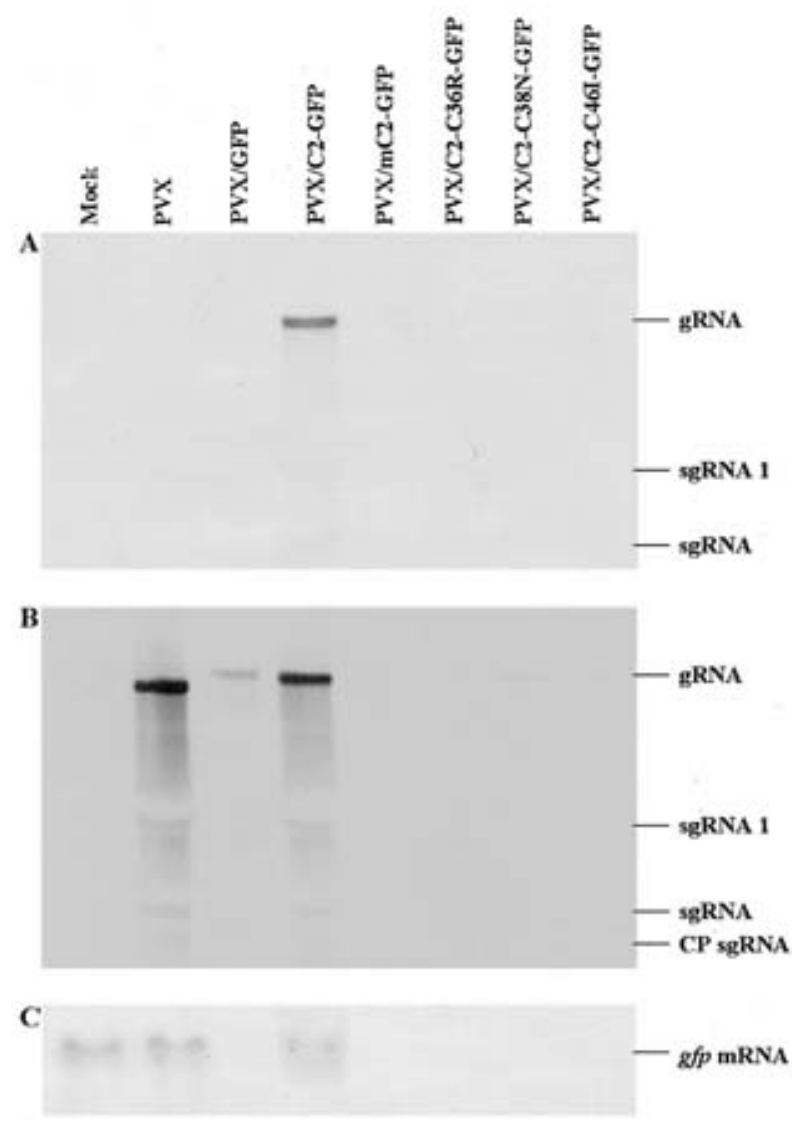

Fig. 6. Northern blot analysis of total RNA extracted at 15 days postinoculation from green fluorescent protein (GFP) transgenic Nicotiana benthamiana plants. Plants were either mock inoculated or infected with Potato virus $X$ (PVX), PVX/GFP, PVX/C2-GFP, PVX/mC2-GFP, PVX/C2 C36R-GFP, PVX/C2-C38N-GFP, and PVX/C2-C46I-GFP. Blots were hybridized with digoxigenin-labeled probes specific to A, the Tomato yellow leaf curl virus-China $C 2$ gene $\mathbf{B}, \mathrm{PVX}$, and $\mathbf{C}$, the gfp gene. The positions of the genomic $(\mathrm{g})$ and subgenomic ( $\mathrm{sg}$ ) RNAs as well as the $g f p$ transgene mRNA are indicated at the right. CP refers to coat protein. 
by in vitro transcription from the SpeI-linearized plasmids. PTGS of GFP and suppression of PTGS was routinely examined under long-wavelength UV light after systemic symptoms appeared. Leaf samples were taken for RNA extraction and northern blot analysis as described above.

\section{ACKNOWLEDGMENTS}

We thank D. Baulcombe for providing the original PVX-based vector and transgenic $N$. benthamiana line 16c, S. Santa Cruz for providing plasmid TXS.GFP-CP, and D. Parry and T. M. A. Wilson for their encouragement throughout this work. This project was partially supported by the Biotechnology and Biological Sciences Research Council.

\section{LITERATURE CITED}

Anandalakshmi, R., Marathe, R., Ge, X., Herr, J. M., Mau, C., Mallory, A., Pruss, G., Bowman, L., and Vance, V. B. 2000. A calmodulin-related protein that suppresses posttranscriptional gene silencing in plants. Science 290:142-144.

Brigneti, G., Voinnet, O., Li, W-X., Ji, L-H., Ding, S-W., and Baulcombe, D. C. 1998. Viral pathogenicity determinants are suppressors of transgene silencing in Nicotiana benthamiana. EMBO J. 17:6739-6746.

Brough, C. L., Sunter, G., Gardiner, W. E., and Bisaro, D. M. 1992. Kinetics of tomato golden mosaic virus DNA replication and coat protein promoter activity in Nicotiana tabacum protoplasts. Virology 187:1-9.

Carrington, J. C., Kasschau, K. D., and Johansen, L. K. 2001. Activation and suppression of RNA silencing by plant viruses. Virology 281:1-5.

Chapman, S., Kavanagh, T., and Baulcombe, D. 1992. Potato virus X as a vector for gene expression in plants. Plant J. 2:549-557.

Dry, I., Krake, L., Mullineaux, P., and Rezaian, A. 2000. Regulation of tomato leaf curl virus gene expression in host tissues. Mol. Plant-Microbe Interact. 13:529-537.

Dry, I. B., Rigden, J. E., Krake, L. R., Mullineaux, P. M., and Rezaian, M. A. 1993. Nucleotide sequence and genome organization of tomato leaf curl virus. J. Gen. Virol. 74:147-151.

Groning, B. R., Hayes, R. J., and Buck, K. W. 1994. Simultaneous regulation of tomato golden mosaic virus coat protein and AL1 gene expression: Expression of the AL4 gene may contribute to suppression of the AL1 gene. J. Gen. Virol. 75:721-726.

Haley, A., Zhan, X. C., Richardson, K., Head, K., and Morris, B. 1992. Regulation of the activities of African cassava mosaic virus promoters by the AC1, AC2 and AC3 gene products. Virology 188:905-909.

Hamilton, W. D. O., Stein, V. E., Coutts, R. H. A., and Buck, K. W. 1984. Complete nucleotide sequence of the infectious cloned DNA components of tomato golden mosaic virus: potential coding regions and regulatory sequences. EMBO J. 3:2197-2205.

Hanley-Bowdoin, L., Settlage, S. B., Orozco, B. M., Nagar, S., and Robertson, D. 1999. Geminivirus: Models for plant DNA replication, transcription, and cell cycle regulation. Crit. Rev. Plant. Sci. 18:71-106.

Hartitz, M. D., Sunter, G., and Bisaro, D. M. 1997. The tomato golden mosaic virus transactivator (TrAP) is a single-stranded DNA and zincbinding phosphoprotein with an acidic activation domain. Virology 263:1-14.
Hong, Y., Saunders, K., Hartley, M. R., and Stanley, J. 1996. Resistance of geminivirus infection by virus-induced expression of dianthin in transgenic plants. Virology 220:119-127.

Hong, Y., Saunders, K., and Stanley, J. 1997. Transactivation of dianthin transgene expression by African cassava mosaic virus AC2. Virology 228:383-387.

Kheyr-Pour, A., Bendahmane, M., Matzeit, V., Accotto, G. P., Crespi, S., and Gronenborn, B. 1991. Tomato yellow leaf curl virus from Sardinia is a whitefly-transmitted monopartite geminivirus. Nucleic Acids Res. 19:6763-6769.

Navot, N., Pichersky, E., Zeidan, M., Zamir, D., and Czosnek, H. 1991. Tomato yellow leaf curl virus: a whitefly-transmitted geminivirus with a single genome component. Virology 185:151-161.

Noris, E., Jupin, I., Accotto, G. P., and Gronenborn, B. 1996. DNA-binding activity of the $\mathrm{C} 2$ protein of tomato yellow leaf curl geminivirus. Virology 217:607-612.

Santa Cruz, S., Chapman, S., Roberts, A. G., Roberts, I. M., Prior, D. A. M., and Oparka, K. J. 1996. Assembly and movement of a plant virus carrying a green fluorescent protein overcoat. Proc. Natl. Acad. Sci. USA 93:6286-6290.

Stanley, J., and Gay, M. R. 1983. Nucleotide sequence of cassava latent virus. Nature 301:2660-2662.

Sung, Y. K., and Coutts, R. H. A. 1996. Potato yellow mosaic geminivirus AC2 protein is a sequence non-specific DNA binding protein. FEBS Lett. 383:51-54.

Sunter, G., and Bisaro, D. M. 1991. Transactivation in a geminivirus: AL2 gene product is needed for coat protein expression. Virology 180:416 419.

Sunter, G., and Bisaro, D. M. 1992. Transactivation of geminivirus AR1 and BR1 gene expression by the viral AL2 gene product occurs at the level of transcription. Plant Cell 4:1321-1331.

Sunter, G., and Bisaro, D. M. 1997. Regulation of a geminivirus coat protein promoter by AL2 protein (TrAP): evidence for activation and derepression mechanisms. Virology 232:269-280.

Tan, P. H. N., Wong, S. M., Wu, M., Bedford, I. D., Saunders, K., and Stanley, J. 1995. Genome organization of ageratum yellow vein virus, a monopartite whitefly-transmitted geminivirus isolated from a common weed. J. Gen. Virol. 76:2915-2922.

Van Wezel, R., Liu, H., Tien, P., Stanley, J., and Hong, Y. 2001. Gene $C 2$ of the monopartite geminivirus tomato yellow leaf curl virus-China encodes a pathogenicity determinant that is localized in the nucleus. Mol. Plant-Microbe Interact. 14:1125-1128.

Voinnet, O. 2001. RNA silencing as a plant immune system against viruses. Trends in Genetics 17:449-459.

Voinnet, O., Lederer, C., and Baulcombe, D. C. 2000. A viral movement protein prevents spread of the gene silencing signal in Nicotiana benthamiana. Cell 103:157-167.

Voinnet, O., Pinto, Y. M., and Baulcombe, D. C. 1999. Suppression of gene silencing: a general strategy used by diverse DNA and RNA viruses of plants. Proc. Natl. Acad. Sci. USA 96:14147-14152.

Wartig, L., Kheyr-Pour, A., Noris, E., Kouchkovsky, D. F., Jouanneau, F., Gronenborn, B., and Jupin, I. 1997. Genetic analysis of the monopartite tomato yellow leaf curl geminivirus: roles of V1, V2, and C2 ORFs in viral pathogenesis. Virology 228:132-140.

Yin, Q., Yang, H., Gong, Q., Wang, H., Liu, Y., Hong, Y., and Tien, P. 2001. Tomato yellow leaf curl China virus: monopartite genome organization and agroinfection of plants. Virus Res. 81:69-76 